\title{
A New Neogregarine Entomopathogen from Crioceris asparagi (Linne, 1758) in Turkey
}

\author{
Hilal Baki
}

Department of Crop and Animal Production, Espiye Vocational School, Giresun University, Giresun 28600, Turkey

\begin{abstract}
In present study, a neogregarine from Crioceris asparagi is reported for the first time in Turkey. C. asparagi (common asparagus beetle) is an important pest of Asparagus officinalis L. crops in Turkey and the world. Therefore, determining of the protist pathogens of C. asparagi is aimed. During the study, a total of 1,099 C. asparagi adults were examined thoroughly using a light microscope. Insects were collected from the provinces of Manisa, Eskişehir and Balıkesir in Turkey, with 117 of them collected from Manisa, 204 of them from Balıkesir and 778 of them from Eskişehir. A neogregarine pathogen was found in Balıkesir and Manisa. Total infection rate was 18\% for Balıkesir between the years 2014-2015 and 15.3\% for Manisa in 2011. Oocysts of the neogregarine pathogen were observed only in malpighian tubes of C. asparagi adults. Fresh mature oocysts of the neogregarine was measured as $9.34 \pm 0.74 \mu \mathrm{m}(n=50)$ in length and $5.27 \pm 0.36 \mu \mathrm{m}(n=50)$ in width. Identification of entomopathogens is prerequisite for their use in biological control.
\end{abstract}

Key words: A. officinalis, C. asparagi, entomopathogen, neogregarine.

\section{Introduction}

Asparagus officinalis is widely cultivated and consumed as a useful vegetable because of medicinal features. A. officinalis, of which the homeland is Western and Southern Africa, Western Asia and Europe, was mostly grown in the Aegean and Marmara Sea side in Turkey. It has a low calorie and is rich in A, B1, B2, B12 and vitamin C [1].

Crioceris asparagi (common asparagus beetle; Coleoptera: Chrysomelidae), is an important pest of $A$. officinalis crops in Turkey, Europe and USA [2-4]. A. Officinalis is the only plant that these insects feed on. The adult beetles and the larvae feed on the asparagus leaves. They also chew the spears; females cement eggs onto spears or ferns. Eggs on asparagus are usually an aesthetic problem, because eggs can not be washed away or easily removed, and they make the plant unmarketable $[5,6]$. In general, protection of plants against pests is performed using chemical insecticides, including carbalyn and permethrin [7].

Corresponding author: Hilal Baki, Ph.D., research field: entomopathogens.
However, the use of chemical insecticides in controlling of the plants that are consumed as food creates serious risks. Naturally occurring entomopathogens can be used instead of chemicals as important regulatory factors in insect populations [8]. The use of entomopathogens as biological control agent is safe for humans and other non-target organisms, and it reduces pesticide residues in food and provides preservation of other natural enemies and biodiversity in managed ecosystems [8]. Entomopathogens can be very effective control agents in some cases [8]. Determination of entomopathogens of C. asparagi is necessary to use in biological control. There are no any papers on protist pathogens of $C$. asparagi from Turkey. There are only faunistical studies on the subfamilies Criocerinae and species of Chrysomelidae families $[9,10]$. Publications that are related with biological control in the world are mostly about parasitoids and predators of $C$. asparagi $[2,11]$. There are a couple records of entomopathogens of this beetle, such as bacteria and fungi, but no record of a neogregarine [11]. Members of Neogregarinorida are entomopathogenic protists. Much like microsporidia, 
these protists are very effective against insect pests in terms of decreasing fecundity and longevity $[12,13]$. Recently, scientists concentrated on using enthomopathogens on biological control in both Turkey and the world. Studies show that Turkey is a very rich country in terms of entomopathogenic organisms, but no record for entomopathogens of $C$. asparagi [14-18]. Possibly, this pathogen could be useful for the control of this beetle. In this study, a neogregarine from C. asparagi populations was reported, and the occurrence and distribution of these pathogens in the male and female C. asparagi adults were studied.

\section{Materials and Methods}

Adult C. asparagi specimens were collected from $A$. officinalis fields from Balıkesir and Manisa in 2011, Balıkesir and Eskişehir in 2014-2015 in Turkey. During the study, a total of 1,099 C. asparagi adults were collected and examined. There were 117 beetles from Manisa and 10 beetles from Balıkesir collected in 2011, and 194 beetles from Balıesir and 778 beetles from Eskişehir collected between 2014 and 2015. All collected insects were transferred to the laboratory and kept refrigerated at $1-4{ }^{\circ} \mathrm{C}$. Each beetle was dissected in ringer solution for presence of pathogen, and its intestine, malpighian tubules, hemolymph and adipose tissue were examined microscopically at magnifications of $40 \times$ to $1,000 \times$ according to Wegensteiner et al. [19] (Nikon Eclips E-400 used). When the oocysts of pathogen was observed, positive wet smears were fixed with methanol for $3 \mathrm{~min}$, and after air drying stained with 5\% Giemsa solution about $10 \mathrm{~h}$. After the staining, smears are washed with distilled water and air dried and examined again for the details of life stages of neogregarine pathogen under the light microscope. This protocol is repeated for each positive smear. Presence of neogregarine was recorded for each adult beetle. Besides, presence of pathogen was also recorded as in male and female insects to compare the infection between both sexes. Oocysts of the neogregarine pathogen were detected in insects, and they were measured and photographed using a Nikon Eclips E-400 and Nicon Eclips Ci microscope with DS-Fi 2 camera attachment. Infection rates was calculated using direct proportion, as calculated by Eq. (1):

$$
\text { Infection rates }=\frac{\text { number of infected beetle }}{\text { number of examined beetle }} \times 100
$$

\section{Results and Discussion}

During the studies, 18 beetles were found to be infected by the neogregarine pathogen from province of Manisa in 2011 (Table 1), while one of 10 beetles collected from province of Balıkesir in 2011 was infected. The rate of infection was low in Manisa and Balıkesir in 2011, $15.3 \%$ and $10 \%$, respectively (Table 1). Total 127 C. asparagi samples were examined from provinces of both Manisa and Balıkesir $(117+10$, respectively) and total infection rate was $14.9 \%$ for two cities in 2011. During the years of 2014-2015, a total of 972 C. asparagi adults were periodically collected from Eskişehir and Balıkesir on May and September. 778 of them were collected from Eskişehir and no infection was found in any of them (Table 2). In 194 C. asparagi adults collected from Balıkesir, 35 were infected by the neogregarine pathogen (Table 3 ). The pathogen was found in $16.5 \%$ of the samples of C. asparagi from Balikesir in 2014, while $20.2 \%$ in 2015, and the total infection rate for the two years was determined to be $18 \%$. No morphological differences were seen between healthy and infected samples. Kleespies et al. [20] and Valles and Pereira [21] reported that there are significant morphological symptoms, such as coloration of insect, irregular pigmentation of compound eyes, etc., on Leptothorax ant infected with neogregarine Mattesia geminate. Furthermore, presence of neogregarine was also examined in male and female insects in terms of sex differences. Although infection rate in females was higher than in male insects there is no remarkable difference between 
Table 1 Infection rates of neogregarine in C. asparagi in Balıkesir and Manisa in 2011.

\begin{tabular}{llllll}
\hline Localities & Year & Month & No. of examined beetles & Neogregarine & Infection rate (\%) \\
\hline Manisa & 2011 & April & 117 & 18 & 15.3 \\
Balıkesir & 2011 & October & 10 & 1 & 10.0 \\
\hline Total & & 127 & 19 & 14.9 \\
\hline
\end{tabular}

Table 2 Infection rates of neogregarine in C. asparagi in Eskişehir in 2014-2015.

\begin{tabular}{|c|c|c|c|c|c|c|c|c|}
\hline \multirow{2}{*}{ Province } & \multirow{2}{*}{ Year } & \multirow{2}{*}{ Month } & \multicolumn{2}{|c|}{ No. of examined beetles } & \multicolumn{2}{|c|}{ Neogregarine } & \multicolumn{2}{|c|}{ Infection rate $(\%)$} \\
\hline & & & $\overline{0}$ & $q$ & $\hat{0}$ & q & $\hat{0}$ & q \\
\hline \multirow{10}{*}{ Eskiş̧ehir } & \multirow{5}{*}{2014} & May & 28 & 32 & - & - & - & - \\
\hline & & June & 73 & 62 & - & - & - & - \\
\hline & & July & 31 & 34 & - & - & - & - \\
\hline & & August & 30 & 32 & - & - & - & - \\
\hline & & September & 14 & 17 & - & - & - & - \\
\hline & \multirow{5}{*}{2015} & May & 45 & 42 & - & - & - & - \\
\hline & & June & 64 & 67 & - & - & - & - \\
\hline & & July & 38 & 43 & - & - & - & - \\
\hline & & August & 40 & 43 & - & - & - & - \\
\hline & & September & 15 & 28 & - & - & - & - \\
\hline Total & & & 378 & 400 & & & & \\
\hline
\end{tabular}

T: male; + : female.

Table 3 Infection rates of neogregarine in C. asparagi in Balıkesir in 2014-2015.

\begin{tabular}{|c|c|c|c|c|c|c|c|c|}
\hline \multirow{2}{*}{ Province } & \multirow{2}{*}{ Year } & \multirow{2}{*}{ Month } & \multicolumn{2}{|c|}{ No. of examined beetles } & \multicolumn{2}{|c|}{ Neogregarine } & \multicolumn{2}{|c|}{ Infection rate $(\%)$} \\
\hline & & & $\overline{0}$ & 우 & $\hat{0}$ & q & $\hat{0}$ & q \\
\hline \multirow{6}{*}{ Balıkesir } & \multirow{3}{*}{2014} & May & 35 & 42 & 6 & 7 & 17.1 & 16.6 \\
\hline & & September & 17 & 21 & 2 & 4 & 11.7 & 19.0 \\
\hline & & Total & 52 & 63 & 8 & 11 & 15.3 & 17.4 \\
\hline & \multirow{3}{*}{2015} & May & 28 & 33 & 6 & 6 & 21.4 & 18.1 \\
\hline & & September & 10 & 8 & 1 & 3 & 10.0 & 37.5 \\
\hline & & Total & 38 & 41 & 7 & 9 & 18.4 & 21.9 \\
\hline$\overline{\text { Total }}$ & & & 90 & 104 & 15 & 20 & 16.6 & 17.5 \\
\hline
\end{tabular}

ô: male; + : female.

sexes. In 2014-2015, total 20 female and 15 male samples from Balıkesir contain neogregarine, and infection rates in different sex are $17.5 \%$ and $16.6 \%$, respectively (Table 3). Yaman and Radek [22] also reported a similar result for a neogregarine infection among male and female Dendroctonus micans populations. They observed the neogregarine pathogen does not favor any sex in $D$. micans. Oocysts that are evidence of the infection of the neogregarine pathogen were observed only in malpighian tubes in samples in this study (Fig. 1). Fresh mature oocysts of the neogregarine were measured as $9.34 \pm 0.74 \mu \mathrm{m}(n=$ $50)$ in length and $5.27 \pm 0.36 \mu \mathrm{m}(n=50)$ in width
(Table 4). During the microscopic examination of wet or stained smear preparations, only oocysts of neogregarine were observed (Fig. 1). Oocysts of the neogregarine are ovoid or lemon-shaped with thick layered walls and distinct plugs in poles (Fig. 1). Neogregarines have especially merogony in their life cycles, which differs from Eugregarines [23, 24]. No different life stages, such as merozoites (macronuclear or macronuclear), gamonts and gametocyst that belonged to pathogen, were observed. To date, there has been no record of pathogens of C. asparagi from Turkey. Existing studies in here are only about its ecology and biology. 


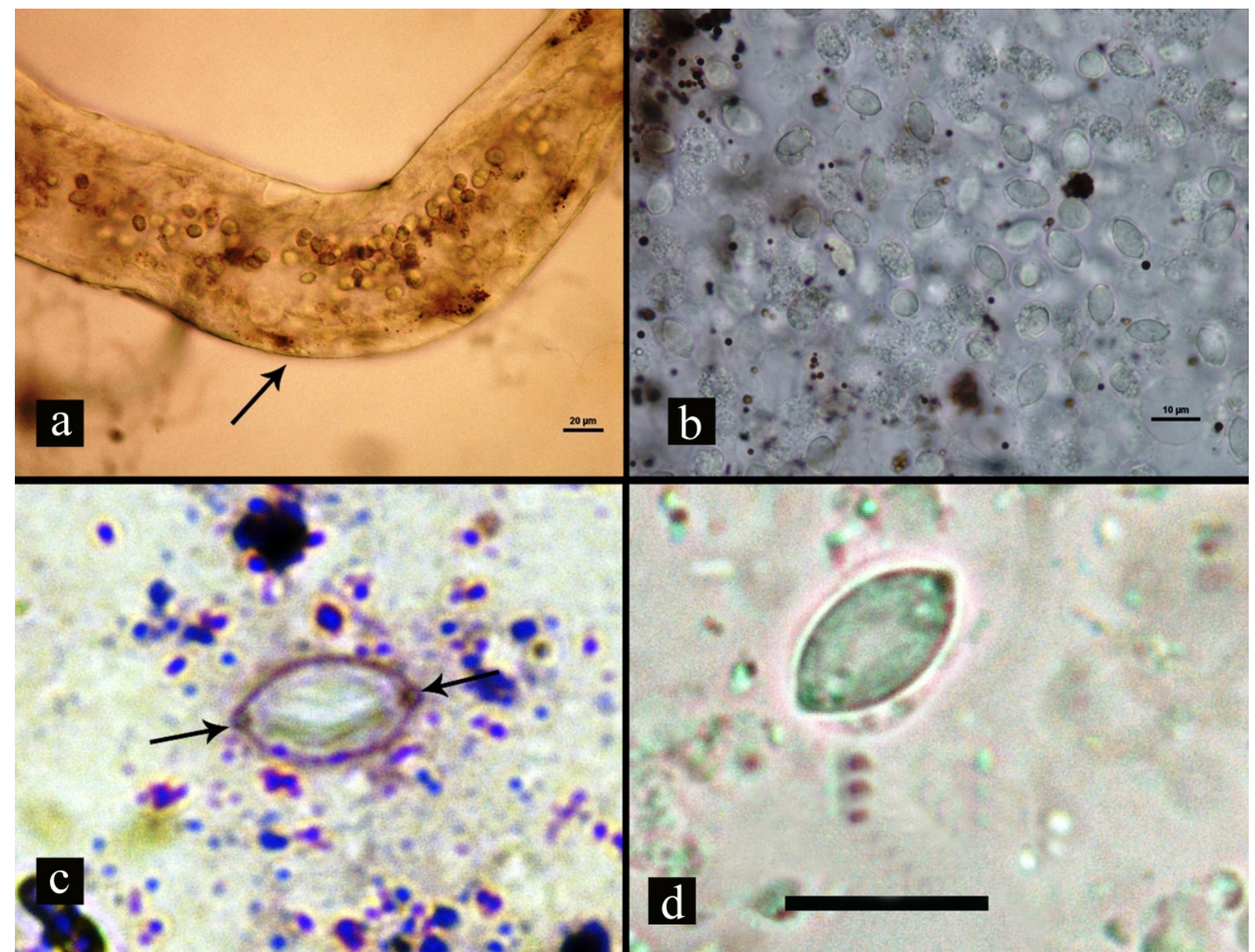

Fig. 1 Fresh oocysts of neogregarine in the malpighi tube (a), fresh oocysts of neogregarine scattered around (b), Giemsa-stained oocysts of neogregarine pathogen (c) and oocysts of neogregarine pathogen in fresh smear (d).

The arrow in Fig. 1a indicating the tube; the arrows in Fig. 1c indicating distinct plugs in poles; the bar in Fig. $1 \mathrm{~d}$ was $10 \mu \mathrm{m}$.

Table 4 Pathogens belonging to neogregarinorida from Turkey.

\begin{tabular}{lllll}
\hline Neogregarine & $\begin{array}{l}\text { Oocysts size } \\
(\mu \mathrm{m})\end{array}$ & Infected tissues & Host & Reference \\
\hline Menzbieria chalcographi & $(11.19 \pm 0.42) \times(4.99 \pm 0.25)$ & Fat bodies & $\begin{array}{l}\text { Dendroctonus micans } \\
\text { (Coleoptera: Scolytinae) }\end{array}$ & {$[22]$} \\
Mattesia sp. & $(11.87 \pm 0.67) \times(6.96 \pm 0.43)$ & Fat bodies & $\begin{array}{l}\text { Rhizophagus grandis } \\
\text { (Coleoptera: Monotomidae) }\end{array}$ & {$[25]$} \\
Mattesia weiseri sp. & $10.90 \times 6.10$ & Fat bodies hemolymph & $\begin{array}{l}\text { Dendroctonus micans } \\
\text { (Coleoptera: Scolytinae) }\end{array}$ & {$[26]$} \\
Neogregarine & $(11.00-12.50) \times(5.00-7.00)$ & Fat bodies & $\begin{array}{l}\text { Melolontha melolontha } \\
\text { (Coleoptera: Scarabaeidae) }\end{array}$ & {$[27]$} \\
Neogregarine & $(9.34 \pm 0.74) \times(5.27 \pm 0.36)$ & Malpighi tubes & $\begin{array}{l}\text { Crioceris asparagi } \\
\text { (Coleoptera: Chrysomelidae ) }\end{array}$ & This study \\
\hline
\end{tabular}

SD: standard deviation

This is the first record of an infection of C. asparagi by the neogregarine pathogen for Turkey, but there are certain records of neogiregarine pathogen from insects that belong to Coleoptera orders. Yaman and Radek [22] found a new neogregarine pathogen, Menzbieria chalcographi, for the first time from a bark beetle Dendroctonus micans. Its oocysts dimension is (11.19 $\pm 0.42) \mu \mathrm{m} \times(4.99 \pm 0.25) \mu \mathrm{m}$ (Table 4). They choose to focus their study on the province of Artvin, Giresun, Trabzon and Ordu due to the fact that the damage of 
Dendroctonus micans is very high in these areas. While no neogregarine infection was found in the province of Trabzon, the neogergarine infection in Artvin was seen to have a high infection rate of $27.3 \%$. In this study, three cities in Turkey were selected in which A. Officinalis is widely grown. While there is no pathogen in Eskişehir, neogregarine was detected in Balıkesir and Manisa. Yaman and Radek [22] stated that the neogregarines was observed in the fat body of adults. Yaman and Radek [26] described the second neogregarine pathogen from Dendroctonus micans, and described it as Mattesia weiseri sp. Nov.. The oocycsts of the pathogen is $10.9 \mu \mathrm{m} \times 6.1 \mu \mathrm{m}$ in size (Table 4). They reported that the infection was seen in fat bodies and hemolymph. Kleespies et al. [20] and Valigurova and Koudela [23] determined a neogregarine pathogen, Mattesia dispora from Ephestia kuehniella, and Mattesia geminiata from Leptothorax ants, respectively. In both of these studies, the infection was similarly seen in fat bodies and hemolymfh of the larvae of the hosts. Lipa and Triggiani [28] observed a new neogregarine in the fat bodies of Apis mellifera and Bombus spp.. In this study, the pathogen was only seen in the malpighi tubes of C. asparagi adults. Member of Neogregarinorida usually causes infection in fat bodies of the host, but Mattesia povolnyi Weiser (a neogregerine pathogen) was infected malpighi tubes on Homoeosoma nebulella (Denis and Schiffermüller) [29]. In addition, an infection of the malpighian tubes causes distribution of neogregarine spores via feces and contamination of eggs during oviposition [29]. McLaughlin and Myers [30] stated that all neogregarine species belonging to genus Ophryocystis were infected in the malphigian tubules of Coleoptera; only the Ophryocystis elektroscirrha sp. were seen in hypodermal tissue of Danaus plexippus from Lepidoptera. Yaman et al. [27] found for the first time a neogregarine pathogen from the population of Melolontha melolontha (Coleoptera: Scarabaeidae) in Kocaeli, Turkey. Total length of oocycsts is 11-12.5 $\mu \mathrm{m}$ in length and 5-7 $\mu \mathrm{m}$ in width (Table 4). They were seen as single forms and not formed in pairs within a gamontocyst, as the case in this study. The infection rate was $36 \%$ in 2013-2014. Lipa and Triggiani [28] measured 11.1-14.4 $\mu \mathrm{m}$ in length and 3.6-5.4 $\mu \mathrm{m}$ in width of the fixed and stained characteristic navicular spores of the neogregarine pathogen. They detected that the infection level was low in hosts in Finland and Italy, but the pathogen has a wide distribution in Europe. Yaman et al. [25] reported a neogregarine pathogen belonging to the genus Mattesia in Rhizophagus grandis (Coleoptera: Monotomidae) that used as predatory insects in biological control of bark beetles. Oocysts of pathogen were measured $11.87 \pm 0.67 \mu \mathrm{m}$ in length and $6.96 \pm 0.43 \mu \mathrm{m}$ in width $(n=60)$ (Table 4$)$. While infection was seen only fat body in Rhizophagus grandis, during the examination of samples in $C$. asparagi, infection was observed only in the malpighian tubes in this study. Žižka et al. [31] found Menzbieria chalcographi in the fat body of Ips typographus L. (Coleoptera: Scolytidae). This neogregarine pathogen causes the death of up to $30 \%$ of the insects, and it can be used as biological control agent against the Ips typographus [31-33]. In addition, at high dosages of the neogregarine pathogen, Ophryocystis elektroscirrha, certain adverse effects are encountered on Danaus plexippus, such as a decrease in larval survival, adult size and life spans [34]. Identification of the neogregarine pathogen from Turkey could potentially be useful for the biological control of this insect. On the other hand, determining of natural pathogens of insect pest reveals the pathogen biodiversity in insect, area and countries. The results of this study allows for comparison of pathogen diversity from different part of Europe, Asia and America for this pest.

\section{Conclusions}

A neogregarine pathogen from C. asparagi has been reported for the first time in Turkey. According 
to the results, it was showed that neogregarine pathogen was detected from Balıkesir and Manisa, while no infection was found from Eskişehir. Examination was carried out based on morphological features. The pathogen has different life stages, but only the oocysts of neogregarine were observed. Oocysts of the neogregarine are lemon-shaped and its dimensions are $(9.34 \pm 0.74) \mu \mathrm{m} \times(5.27 \pm 0.36) \mu \mathrm{m}$. The pathogen was observed only in malpighian tubes in samples. Neogregarine was also found in both male and female samples and there is no remarkable difference between sexes.

\section{Acknowledgments}

The author is grateful to the Giresun University for finance support as a scientific research project FEN-BAP-A-250414-47 in Turkey.

\section{References}

[1] Saito, M., Rai, D. R., and Masuda, R. 2000. "Effect of Modified Atmosphere Packaging on Glutathione and Ascorbic Acid Content of Asparagus Spears." Food Processing and Preservation 24 (3): 243-51.

[2] Capinera, J. L., and Lilly, J. H. 1975. "Bionomics and Biotic Control of the Asparagus Beetle, Crioceris asparagi, in Western Massachusetts." Environ. Entomol. 4 (1): 93-6.

[3] McNeil, E., and Strzelecki, K. K. 1995. "Asparagus Production and Trade in Selected Countries." World Horticultural Trade and US Export Opportunities 9: 18-27.

[4] LeSage, L., Dobesberger, E. J., and Majka, C. G. 2008. "Introduced Leaf Beetles of the Maritime Provinces: Part 6, the Common Asparagus Beetle, Crioceris asparagi (Linnaeus), and the Twelve-Spotted Asparagus Beetle, Crioceris duodecimpunctata (Linnaeus) (Coleoptera: Chrysomelidae)." Proc. Entomol. Soc. of Washington 110 (3): 602-21.

[5] Hodgson, E. W., and Drost, D. 2007. Asparagus Beetle and Spotted Asparagus Beetle. ENT-75-07PR, Utah Plant Pest Diagnostic Laboratory, Utah State University Extension, September 2007.

[6] Brust, E. G. 2010. Asparagus Beetle Damage Greater This Season. Vegetable Insect IPM, University of Maryland Extension.

[7] UT Extension. 2006. "You Can Control Garden Insects." PB595, the University of Tennessee Agricultural
Extension Service. Accessed July 21, 2016. https://extension.tennessee.edu/publications/Documents/P B595.pdf.

[8] Lacey, L. A., Frutos, R., Kaya, H. K., and Vail, P. 2001. "Insect Pathogens as Biological Control Agents: Do They Have a Future." Biol. Control 21 (3): 230-48.

[9] Turanl1, F., Kaya, F., and Kismal1, S. 2002. "Faunistic Studies on the Species of the Subfamily Criocerinae and Cryptocephalinae (Coleoptera: Chrysomelidae)." Turk. Entomol. Derg-Tu. 26: 301-6.

[10] Özdikmen, H., and Turgut, S. 2008. "The Subfamily Criocerinae of Turkey (Coleoptera: Chrysomelidae) with Two New Records and Zoogeographical Remarks." Munis Ent. Zool. 3 (1): 239-52.

[11] Morrison III, W. R., and Szendrei, Z. 2014. "The Common Asparagus Beetle and Spotted Asparagus Beetle (Coleoptera: Chrysomelidae): Identification, Ecology and Management.” J. Integ. Pest Mngmt. 5 (3): 1-6.

[12] Cowley, J. M. 1989. "Effect of Disease Caused by a Neogregarine Protozoan (Mattesia sp.) on the Population Dynamics of a Hill Country Sod Webworm (Eudonia sabulosella, Pyralidae: Scopariinae)." J. Invertebr. Pathol. 53 (2): 159-63.

[13] Kumano, N., Iwata, N., Kuriwada, T., Shiromoto, K., Haraguchi, D., Yasunaga-Aoki, C., and Kohama, T. 2010. "The Neogregarine Protozoan Farinocystis sp. Reduces Longevity and Fecundity in the West Indian Sweet Potato Weevil, Euscepes postfasciatus (Fairmaire)." J. Invertebr. Pathol. 105 (3): 298-304.

[14] Tosun, O., Yaman, M., and Aydın, Ç. 2008. "Parasites of Phyllotreta atra (Fabricius, 1775) (Coleoptera: Chrysomelidae) in Trabzon." Turkiye Parasitol. Derg. 32 (2): 153-7.

[15] Aydin, C., Yaman, M., and Tosun, O. 2009. "Distribution of Nosema phyllotretae (Microspora, Nosematidae) Weiser, 1961 in Populations of Phyllotreta atra (Coleoptera, Chrysomelidae) in Turkey." Turkiye Parasitol. Derg. 33 (2): 165-8.

[16] Ünal, S., Yaman, M., Tosun, O., and Aydın, Ç. 2009. "Occurrence of Gregarina typographi (Apicomplexa, Gregarinidae) and Metschnikowia typographi (Ascomycota, Metschnikowiaceae) in Ips sexdentatus (Coleoptera: Curculionidae, Scolytinae) Populations in Kastamonu (Turkey).” J. Anim. Vet. Adv. 8 (12): 2687-9.

[17] Yaman, M., and Baki, H. 2010. "The First Record of Gregarina typographi Fuchs. (Protista: Apicomplexa: Gregarinidae) from the European Spruce Bark Beetle, Ips typographus (Linnaeus) (Coleoptera: Curculionidae, Scoltinae) in Turkey." Turkiye Parazitol. Derg. 34: 179-82.

[18] Yaman, M., and Baki, H. 2011. "First Record of 
Entomopoxvirus of Ips typographus (Linnaeus) (Coleoptera: Curculionidae, Scoltinae) for Turkey." Acta Zool. Bulgar. 63 (2): 199-202.

[19] Wegensteiner, R., Weiser, J., and Fuhrer, E. 1996. "Observations on the Occurrence of Pathogens in the Bark Beetle Ips typographus L. (Coleoptera, Scolytidae)." J. Appl. Entomol. 120: 199-204.

[20] Kleespies, R. G., Huger, A. M., Buschinger, A., Nähring, S., and Schumann, R. D. 1997. "Studies on the Life History of a Neogregarine Parasite Found in Leptothorax ants from North America." Biocontrol Sci. Tech. 7 (1): 117-30.

[21] Valles, S. M., and Pereira, R. M. 2003. "Use of Ribosomal DNA Sequence Data to Characterize and Detect a Neogregarine Pathogen of Solenopsis invicta (Hymenoptera: Formicidae).” J. Invertebr. Pathol. 84 (2): 114-8.

[22] Yaman, M., and Radek, R. 2012. "Menzbieria chalcographi, a New Neogregarine Pathogen of the Great Spruce Bark Beetle, Dendroctonus micans (Kugelann) (Curculionidae: Scolytinae)." Acta Parasitol. 57 (3): 216-20.

[23] Valigurova, A., and Koudela, B. 2006. "Ultrastructural Study of Developmental Stages of Mattesia dispora (Neogregarinorida: Lipotrophidae), a Parasite of the Flour Moth Ephestia kuehniella (Lepidoptera)." Eur. J. Protistol. 42 (4): 313-23.

[24] Vega, F. E., and Kaya, H. K. 2012. Insect Pathology, 2nd ed.. San Diego, USA: Academic Press, 377-87.

[25] Yaman, M., Radek, R., and Linde, A. 2012. "A New Neogregarine Pathogen of Rhizophagus grandis (Coleoptera: Monotomidae)." North-Western J. Zool. 8 (2): 353-7.

[26] Yaman, M., and Radek, R. 2015. "Mattesia weiseri sp. nov., a New Neogregarine (Apicomplexa: Lipotrophidae) Pathogen of the Great Spruce Bark Beetle, Dendroctonus micans (Coleoptera: Curculionidae, Scolytinae)." Parasitol. Res. 114 (8): 2951-8.

[27] Yaman, M., Alg1, G., Güner, B. G., Ertürk, Ö., Ünal, S., and Radek, R. 2015. "First Record, Occurrence and Distribution of Entomopathogens in Populations of the European Cockchafer, Melolontha melolontha (Coleoptera: Scarabaeidae) in Turkey." North-Western J. Zool. 12 (1): 192-5.

[28] Lipa, J. J., and Triggiani, O. 1992. "A Newly Recorded Neogregarine (Protozoa, Apicomplexa), Parasite in Honey Bees (Apis mellifera) and Bumble Bees (Bombus spp).” Apidologie 23 (6): 533-6.

[29] Weiser, J. 1953. "Schizogregarines from Flour in Flour Storage.” Vest. Cesk. Spol. Zool. 17: 199-211.

[30] McLaughlin, R. E., and Myers, J. 1970. "Ophryocystis elektroscirrha sp. n., a Neogregarine Pathogen of the Monarch Butterfly Danaus plexippus (L.) and the Florida Queen Butterfly D. gilippus berenice Cramerl.” Journal of Eukaryotic Microbiology 17 (2): 300-5.

[31] Žižka, Z., Weiser, J., and Wegensteiner, R. 1996. "Ultrastructures of Oocysts of Mattesia sp. (Neogregarina) in the Fat Body of Ips typographus (Coleoptera: Scolytidae)." J. Eukaryot Microbiol. 44 (1997): 26A.

[32] Žižka, Z., Weiser, J., and Wegensteiner, R. 1997. "Ultrastructures of Syzygies and Gametocysts of Mattesia sp. in the Bark Beetle Ips typographus." Eukaryot Microbiol. 45 (1998): 8A.

[33] Weiser, J., Pultar, O., and Žižka, Z. 2000. Biological Protection of Forest against Bark Beetle Outbreaks with Poxvirus and Other Pathogens. The International Union of Air Pollution Prevention and Environmental Protection Associations (IUAPPA), Praha.

[34] Altizer, S. M., and Oberhauser, K. S. 1999. "Effects of the Protozoan Parasite Ophryocystis elektroscirrha on the Fitness of Monarch Butterflies (Danaus plexippus)." J. Invertebr. Pathol. 74 (1): 76-88. 